\title{
Zika Virus Iceberg: Very Large
}

A ragao et al ${ }^{1}$ reported an interesting finding in "Nonmicrocephalic Infants with Congenital Zika Syndrome Suspected Only after Neuroimaging Evaluation Compared with Those with Microcephaly at Birth and Postnatally" and raised an interesting question, "How Large Is the Zika Virus 'Iceberg'?" In the report by Aragao et al, the important observations are "Among 77 infants, $24.6 \%$ had congenital Zika syndrome (11.7\% microcephaly at birth, $9.1 \%$ postnatal microcephaly, 3.9\% without microcephaly)." It is interesting that there are many children with congenital Zika virus syndrome with no microcephaly but abnormal neurologic findings from neuroimaging evaluation. This finding might imply that there may be many cases of Zika infection that present no external phenotypic abnormality but have hidden neurologic abnormalities. The cases with Zika virus infections are usually asymptomatic, ${ }^{2}$ and the tip of iceberg phenomenon is usually mentioned.

Regarding the magnitude of underdiagnosed "iceberg" Zika virus infection, one might assume that $0.96 \%$ of infected cases (3.9\% from $24.6 \%$ ) can be underdiagnosed if there is no neuroimaging evaluation. Based on a recent publication of an immuno- logic study in an endemic area in Southeast Asia, the silent immunologic asymptomatic cases are $63 \% .{ }^{4}$ This finding can imply that the Zika virus iceberg is very large, and it might be necessary to consider the role and cost-effectiveness of using laboratory tools, including neuroimaging, for assessment of any suspicious cases.

\section{REFERENCES}

1. Aragao MFVV, Holanda AC, Brainer-Lima AM, et al. Nonmicrocephalic infants with congenital Zika syndrome suspected only after neuroimaging evaluation compared with those with microcephaly at birth and postnatally: how large is the Zika virus "iceberg"? AJNR Am J Neuroradiol 2017;38:1427-34 CrossRef Medline

2. Wiwanitkit $S$, Wiwanitkit V. Afebrile, asymptomatic and non-thrombocytopenic Zika virus infection: don't miss it! Asian Pac J Trop Med 2016;9:513 CrossRef Medline

3. Duarte G, Moron AF, Timerman A, et al. Zika virus infection in pregnant women and microcephaly. Rev Bras Ginecol Obstet 2017;39: 235-48 CrossRef Medline

4. San K, Rajadhan V. Seroprevalence of Zika virus in Cambodia: a preliminary report. Adv Lab Med Int 2016;6:37-40

(D) W. Sriwijitalai RVT Medical Center Bangkok, Thailand (D) V. Wiwanitkit Joseph Ayobabalola University Lagos, Nigeria 